\title{
Prevalence and Predisposing Factors of Subclinical Mastitis in Dairy Farm Deyeng Village Kediri District, East Java, Indonesia
}

\author{
Ani Setianingrum \\ Laboratory of veterinary Public \\ Health \\ Faculty of Veterinary Medicine \\ Universitas Brawijaya \\ Malang, Indonesia \\ ani.setia@ub.ac.id \\ Mira Fatmawati \\ Laboratory of veterinary Public \\ Health \\ Faculty of Veterinary Medicine \\ Universitas Brawijaya \\ Malang, Indonesia \\ mirafkh36@gmail.com
}

\author{
Masdiana Chendrakasih Padaga \\ Laboratory of veterinary Public \\ Health \\ Faculty of Veterinary Medicine \\ Universitas Brawijaya \\ Malang, Indonesia \\ mpadaga@gmail.com
}

Fidi Nur Aini Eka Puji Dameant

Laboratory of veterinary Public Health

Faculty of Veterinary Medicine Universitas Brawijaya

Malang, Indonesia

fididameanti88@gmail.com

\author{
Manik Eirry Sawitri \\ Laboratory of Husbandry Technology \\ Faculty of Husbandry \\ Universitas Brawijaya \\ Malang, Indonesia \\ maniksawitri@gmail.com
}

\author{
Zahrania Marsha Amira Sulherman \\ Graduate Student \\ Faculty of Veterinary Medicine \\ Universitas Brawijaya \\ Malang, Indonesia \\ zahraniamarsha@gmail.com
}

\begin{abstract}
Subclinical mastitis in dairy farm can cause many impact in milk production which lead to economic loss for farmers. The average of subclinical mastitis in East Java is $70-80 \%$ with average on milk yield loss about 2-3 liters per day. Early detection on subclinical mastitis in dairy cows are important to reduce potential problems infection spreading caused by infected udder. Indirect test using California mastitis test (CMT) can be used in the field to detect subclinical mastitis. This research aim was to determine the prevalence and predisposing factors of subclinical mastitis in traditional dairy farm Sukses Bersama Jaya, located in Deyeng village, Kediri district of East Java province. Study was conduct on August to September 2018 in total of 47 lactating cows from 13 farmers using CMT. Predisposing factors assessed using closed questionnaire given to all farmers. Of the total animal examined, $21.3 \%(10 / 47)$ had subclinical mastitis. Predisposing factors differs significantly $(\mathbf{P}<\mathbf{0 . 0 5})$ to subclinical mastitis prevalence were udder morphology, number of lactation, and dry period treatments. Udder morphology associated to subclinical mastitis $(\chi 2=11.0$, $\mathbf{P}<\mathbf{0 . 0 5}$ ), udder with strong suspensory ligament were more affected (OR 0.628; 95\%; CI 0.14-2.83). Treatments during dry periods significantly associated with subclinical mastitis $(\chi 2=30.43, P<0.05)$, un-treatment cows have greater risk (OR $0.07 ; 95 \%$; CI $0.03-0.22$ ). Lack on personal hygiene was noticed as all of farmers did not wash their hands using soap before milking process and Teat dipping was not practiced by all farmers $(\mathbf{1 0 0 \%})$. It can be concluded that prevalence on subclinical mastitis in Sukses Bersama Jaya farm was low compared to average prevalence in East Java. Most farmers were already practicing good dairy management, although improvements on personal hygiene were still needed.
\end{abstract}

Keywords—subclinical mastitis, prevalence, predisposing factors

\section{INTRODUCTION}

Dairy farm system in Indonesia mostly, by $90 \%$ are still traditional farming where farmers use as a source of family income [1]. Farmers especially in countryside, invested most of their money on cattle farming due to cattle price are high, so they can get more profit. Dairy cows were introduced to Indonesian people at the end of $19^{\text {th }}$ century, it means dairy cattle are already known and use as milk producing livestock for more than 125 years. National population of dairy cows by years 2018 was 550,000 with East Java population was 283,311 [2]. Dairy cattle population in East Java were more than half national population. Traditional dairy farming is the most common farming system with small scale farm, each farmer owns 1 to 3 dairy cows. According to Taslim [3] farming scale associated with social economic status, technology, financing, resources and field area.

Mastitis is the most prevalent production disease in dairy cattle, and still the most common problem to dairy farmers. Manifestation of mastitis is clinical and subclinical mastitis. Farmers recognize clinical mastitis by the clinical symptoms [4]. Subclinical mastitis is difficult to detect due to the absence of any visible indications, and it has major cost implications. Moreover, mastitis affects milk quality directly in the technical characteristic and the hygienic quality of the milk, and indirectly to intrinsic milk quality [5].

Subclinical mastitis can be diagnosed by increased number of somatic cell count in milk and increased bacterial number inside cow's udder. Inflammation response due to infection can be measure using indirect test such as California Mastitis Test (CMT) or direct test using somatic cell count method [6]. Subclinical mastitis prevalence in dairy farm can reach 14 to 40 times more than clinical 
mastitis and can become the source of infection to the herd [7].

Mastitis in dairy cattle affected by many predisposing factors. These factors are number of livestock, climate, social culture, milk distribution systems, farmer's education, farming management are important factors implicate subclinical mastitis case [8].

Deyeng village in Kediri district is lowland region which is not common for dairy farming. "Sukses Bersama Jaya" farm has been in the dairy industry for more than 5 years and increased in population and milk production. This research purpose was to evaluate the prevalence of subclinical mastitis in Deyeng village and to analysed predisposing factors associated to mastitis.

\section{MATERIALS AND METHODS}

\section{A. Sampling and mastitis test}

This research was cross sectional field study using purposive sampling method. The study conduct on dry season August to September 2018. Criteria for dairy cows were lactating period 2 to 3 months from 13 farmers. Total number of sample was 47 dairy cows. Detection of mastitis on the field using California mastitis test (CMT) at morning with enough light to ensure the results were accurate. A four well plastic paddle were used, one well for each teat. Foremilk was discarded then milk samples from each teat mixed with CMT reagent at equal volume, and gently agitated horizontally for 10 seconds. The reaction was scored according to Subronto [9] on Table I.

TABLE I. CALIFORNIA MASTITIS TEST INTERPRETATION

\begin{tabular}{|c|l|l|}
\hline Symbol & \multicolumn{1}{|c|}{ Reaction } & \multicolumn{1}{c|}{ Est somatic cell count } \\
\hline- & No precipitation & $<10.000-200.000$ \\
$\mathrm{~T}$ & Trace & $150.000-500.000$ \\
+ & Precipitation, no gel formed & $400.000-1.500 .000$ \\
++ & Thick liquid & $800.000-5.000 .000$ \\
+++ & Gel formed mix & $>5.000 .000$ \\
\hline
\end{tabular}

\section{B. Data collection}

Variables relating to predisposing factors were collected by means of closed questionnaire to all 13 farmers as respondent. Farm-level data recorded included information on milking practices, general cleaning practices. Information about the cows included age, breed, parity, milk yield, and information whether it had clinical mastitis before Statistical analyses using analyses of variant (ANOVA) and cross tabs analyses for factors associated to mastitis.

\section{RESULTS}

All dairy farmers in Sukses Bersama Jaya farm, Deyeng village were interviewed, resulting in a 100 per cent voluntary response rate for participation in this study. Quarter milk samples were tested by CMT, results showed on Table II. Depending on CMT results, cases were categorized as positive or negative. Positive results on CMT categorized as subclinical mastitis. The prevalence of sub clinical mastitis the total 47 lactating cows examined was $21.3 \%(10)$.
TABLE II. CMT RESUlTS ON QUARTER MILK SAMPLES

\begin{tabular}{|c|c|c|c|c|}
\hline \multirow{2}{*}{ CMT } & \multicolumn{4}{|c|}{ Udder quarter } \\
\cline { 2 - 5 } & $\begin{array}{c}\text { Front } \\
\text { Right }\end{array}$ & Rear right & Front Left & Rear Left \\
\hline- & 41 & 41 & 45 & 42 \\
+ & 5 & 5 & - & 3 \\
++ & - & - & 1 & 1 \\
+++ & 1 & 1 & 1 & 1 \\
\hline
\end{tabular}

\section{A. Risk factors associated with subclinical mastitis}

The association of the cow and farm level at $\mathrm{P} \leq 0.05$ to subclinical mastitis during the univariate analysis were number of lactation $(\mathrm{P}=0.028)$, udder morphology $(\mathrm{P}=0.04)$ and dry period treatments $(\mathrm{P}=0.00)$. the analysis of variant results on predisposing factors related to subclinical mastitis shown in Table III.

TABLE III. PREDisPosing Factors Related To SubclinicAL MASTITIS

\begin{tabular}{|c|c|c|c|}
\hline Variables & Description & Results & $\mathrm{P}$ value \\
\hline \multirow[t]{2}{*}{ Age } & $<5$ years & 29 & \\
\hline & $\geq 5$ years & 27 & \\
\hline \multirow[t]{2}{*}{$\begin{array}{l}\text { Number of } \\
\text { lactation }\end{array}$} & $<3$ & 29 & $0.028^{*}$ \\
\hline & $\geq 3$ & 18 & \\
\hline \multirow[t]{5}{*}{$\begin{array}{l}\text { Udder } \\
\text { morphology }\end{array}$} & $\begin{array}{l}\text { Very strong } \\
\text { suspensory ligament }\end{array}$ & 10 & $0.04^{*}$ \\
\hline & $\begin{array}{l}\text { Strong suspensory } \\
\text { ligament }\end{array}$ & 18 & \\
\hline & $\begin{array}{l}\text { Udder attachment } \\
\text { moderate }\end{array}$ & 17 & \\
\hline & $\begin{array}{l}\text { Udder attachment } \\
\text { weak }\end{array}$ & 2 & \\
\hline & Low udder and teat & 0 & \\
\hline \multirow[t]{2}{*}{$\begin{array}{l}\text { Milking } \\
\text { frequency }\end{array}$} & 1 per day & 1 & \\
\hline & 2 per day & 46 & \\
\hline \multirow[t]{2}{*}{$\begin{array}{l}\text { Pen } \\
\text { Cleanliness }\end{array}$} & Daily cleaning & 46 & \\
\hline & No cleaning & 1 & \\
\hline \multirow[t]{2}{*}{ Bathing cows } & yes & 47 & \\
\hline & no & 0 & \\
\hline \multirow{2}{*}{$\begin{array}{l}\text { Dry period } \\
\text { medication }\end{array}$} & medicated & 7 & $0.00^{*}$ \\
\hline & Not medicated & 40 & \\
\hline \multirow{2}{*}{$\begin{array}{l}\text { Teat dipping } \\
\text { after milking } \\
\text { process }\end{array}$} & yes & 0 & \\
\hline & & 47 & \\
\hline \multirow{2}{*}{$\begin{array}{l}\text { Washing hands } \\
\text { using soap } \\
\text { before milking }\end{array}$} & yes & 0 & \\
\hline & no & 47 & \\
\hline
\end{tabular}

The final models for risks factors of subclinical mastitis in dairy farm Sukses Bersama Jaya, Deyeng village defined by CMT positive shown in Table IV. Occurrence of subclinical mastitis was significantly influenced by udder morphology $\left(\chi^{2}=11.0, \mathrm{P}<0.05\right)$ and dry period medication $\left(\chi^{2}=30.25, \mathrm{P}<0.05\right)$. udder with strong suspensory ligament were more affected (OR 0.628; 95\%; CI 0.14-2.83) untreatment cows have greater risk (OR 0.07 ; 95\%; CI 0.03 $0.22)$. 
TABLE IV. RISKS FACTORS OF SUBCLINICAL MASTITIS SUKSES Bersama Jaya Farm DEYeng Village, KEDIRI

\begin{tabular}{|c|c|c|c|}
\hline Variables & $\chi^{2}$ & $P$ value & OR $(95 \%$ CI $)$ \\
\hline $\begin{array}{l}\text { Udder morphology } \\
\text { Very strong } \\
\text { suspensory ligament } \\
\text { Strong suspensory } \\
\text { ligament } \\
\text { Udder attachment } \\
\text { moderate }\end{array}$ & 11.00 & $0.012^{*}$ & $\begin{array}{c}0.628(0.14-2.83) \\
2.083(0.50-8.60) \\
5.625(3.00- \\
10.54)\end{array}$ \\
\hline $\begin{array}{l}\text { Number of lactation } \\
<3 \\
>3\end{array}$ & 8.25 & 0.22 & $\begin{array}{c}0.32(0.07-1.35) \\
3.12(0.74-13.19)\end{array}$ \\
\hline $\begin{array}{l}\text { Dry period medication } \\
\text { Medicated } \\
\text { Not medicated }\end{array}$ & 30.43 & $0.00^{*}$ & $\begin{array}{c}13.33(4.49- \\
39.59) \\
0.07(0.03-0.22)\end{array}$ \\
\hline
\end{tabular}

\section{DISCUSSION}

Subclinical mastitis case in this study based on CMT positive was $21.3 \%$ lower than the prevalence of subclinical mastitis reported in Indonesia which reached $75 \%$ to $83 \%$ [10]. However, this study was only in small scale farm with the general hygiene and sanitation on milking process were already applied. According to Sugiri \& Anri [11] study, subclinical mastitis prevalence on small scale to middle scale dairy farms in Java at 2008-2010 period was $85 \%$. Mastitis in dairy cows is a problem to farmers due to the impact on dairy production such as decreased milk quality and milk yield causing early culling on productive age cows. Decreased on milk yield about 15 to 30 per cent per lactation per cows is a big problem in dairy industry [12].

Predisposing factors differs significantly $(\mathrm{P}<0.05)$ to subclinical mastitis prevalence shown on table III were udder morphology, number of lactation, and dry period treatments. Udder morphology associated to subclinical mastitis $(\chi 2=11.0, \quad \mathrm{P}<0.05)$, udder with very strong suspensory ligament were more affected (OR $0.628 ; 95 \%$; CI 0.14-2.83). Occurrence of mastitis may be influenced by some heritable characteristics such as capacity of milk production, teat structures, and udder conformation [13].

Treatments during dry periods significantly associated with subclinical mastitis $(\chi 2=30.43, \mathrm{P}<0.05)$, un-treatment cows have greater risk (OR 0.07; 95\%; CI 0.03-0.22). Absence of dry cow therapy regime could possibly be among the major factor contributing to high prevalence at early lactation. During a dry period due to the low bactericidal and bacteriostatic qualities of milk, the pathogens can easily penetrate into the teat canal and multiply; this can be carried over into the post-parturient period and ultimately develop into clinical mastitis [14].

Lack on personal hygiene was noticed as all of farmers did not wash their hands using soap before milking process and Teat dipping was not practiced by all farmers (100\%). Antibiotics treatments during dry period can be use as mastitis prevention in dairy cattle $[14,15]$. Although this treatment was not always having significant effect on field.
In this study, 7 of 10 cows' positive subclinical mastitis were given treatments on dry period.

Inadequate hygienic condition of dairy environment, poor animal health service, and lack of proper attention to health of the mammary gland were important predisposing factors of mastitis in the area. Adequate housing with proper sanitation and regular screening for early detection and treatment.

\section{ACKNOWLEDGMENT}

This research was carried out by a grant received from the "Program Pengabdian Masyarakat Doktor Mengabdi" Universitas Brawijaya, Malang, Indonesia year 2018-2019.

\section{REFERENCES}

[1] Mubyarto. 1995. Pengantar Ekonomi Pertanian. LP3ES Yogyakarta.

[2] Direktorat Jenderal Peternakan dan Kesehatan Hewan Kementerian Pertanian RI Livestock and Animal Health Statistics 2018

[3] Taslim. 2011. Jurnal Ilmu Ternak. No. 10 Vol. 1 52-56.

[4] Sutarti, E., Budiharta, S., \& Sumiarto, B. 2003. Prevalensi dan Faktor-Faktor Penyebab Mastitis Pada Sapi Perah Rakyat di Kabupaten Semarang Propinsi Jawa Tengah. Jurnal Sain Vet, 21(1), 43-49.

[5] Hogeveen, H., \& Lankveld, J.M. 2002. Economics of milk quality some starting points for discussion.

[6] Yalcin, C. 1996. The economic Impact of mastitis contro Procedures in Scottish Dairy Herds. ProQuest Dissertations \& Theses Global.

[7] Patnaik, S., Prasad, A., Ganguly, S., Piste, P. B., Kanase, S. M., \& Shevale, S. B. 2013. Mastitis, an Infection of Cattle Udder: A Review. Journal of Chemical, Biological and Physical Sciences, 3(3), 1746-1750.

[8] FAO. 2014. Impact of Mastitis in Small Scale Dairy Production Systems (No. 13). Animal Production and Health Working Paper No.13. Rome.

[9] Subronto. 1995. Ilmu penyakit ternak. Gadjah Mada University Press. Yogyakarta

[10] Sudarwanto, M, \& Sudarnika, E. 2006. Nilai Diagnostik Tes IPB Mastitis dibandingkan dengan Jumlah Sel Somatik dalam Susu, 1, $1-2$.

[11] Sugiri, Y. dan A. Anri. 2014. Prevelensi patogen penyebab masttis subklinis (Staphylococcus aureus dan Streptococcus agalactiae) dan patogen penyebab mastitis subklinis lain pada peternak skala kecil dan menengah di beberapa sentra peternakan sapi perah di Pulau Jawa. Balai Pengujian dan Penyidikan Penyakit Hewan dan Kesmavet, Lembang, Bandung.

[12] Sudarwanto, M, \& Sudarnika, E. 2008. Hubungan antara pH Susu dengan Jumlah Sel Somatik Sebagai Parameter Mastitis Subklinik. Media Peternakan, 31(2), 107-113.

[13] Radostits, O. M., C.C.Gay, Hinchcliff, K. W., \& Constable, P. D 2007. Disease caused by Bacillus anthracis species. In Veterinary Medicine: a textbook of the diseases of cattle, sheep, goats, pigs and horses. 10th ed., pp. 816-822. London: Elsevier.

[14] Halasa T, Nielen M, van Werven T, Hogeveen H. 2010. A simulation model to calculate costs and benefits of dry period interventions in dairy cattle. Livest Sci. 129:80-87.

[15] Bhutto AL, Murray RD, Woldehiwet Z. 2011. The effect of dry cow therapy and internal teat-sealant on intra- mammary infections during subsequent lactation. Res Vet Sci. 90:316-320. 